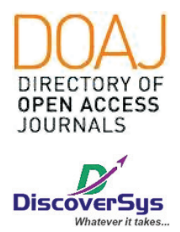

Published by DiscoverSys

\section{Gambaran perkembangan kognitif dan bahasa pada anak usia di bawah 3 tahun di Taman Pengasuhan Anak (TPA)/(Daycare) Kota Denpasar, Bali}

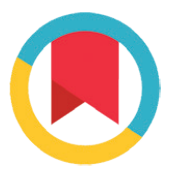

CrossMark

\author{
I Gusti Istri Agung Widnyani, ${ }^{1 *}$ I Gusti Ayu. Trisna Windiani, ${ }^{1}$ I Gusti Agung Ngurah \\ Sugitha Adnyana, ${ }^{1}$ Soetjiningsih ${ }^{1}$
}

\title{
ABSTRACT
}

Background: Speech and language developmental disorders can affect various functions in learning difficulties. This often happens to children who are less stimulated because today, many parents work so that child care will be reduced. Therefore, the childcare park (TPA) can be a choice of place to leave the child so that it is expected to get proper stimulation according to age level. This study aims to assess the status of cognitive and language development in children under 3 years of age at the Denpasar City, Bali.

Methods: A cross-sectional study was conducted to 48 children who were in 4 TPAs in Denpasar during February 2018. Variables assessed in this study included cognitive and language aspects using adaptive cognitive test (CAT) / clinical linguistic \& auditory milestone scale questionnaires. (CLAMS) that is valid and reliable. The research data obtained were analyzed using SPSS software version 19 for Windows.
Results: Most respondents were female (56.3\%), mean age $19.5 \pm 10.0$ months, and have high levels of education for both fathers (87.5\%) and mothers (91.7\%). The Caput Scale results show that the average DQ CAT value is $98.1 \pm 11.0$, DQ CLAMS $92.1 \pm$ 12.0, and FSDQ $95.1 \pm 11.0$. As many as $27.1 \%$ of children in TPA have abnormal FSDQ score. The FSDQ score of the respondent's characteristics showed that most of the normal values were obtained for male (76.2\%), high education on fathers (78.5\%) and mothers (77.2), as well as jobs as a civil servant for fathers (73.3) and mothers (78.6)

Conclusion: About $27.1 \%$ of children experience cognitive and language impairment in TPA through CAT/CLAMS examination. In this regard, further assessment with a better research design is needed to find a causal effect.

Keywords: TPA, CAT/CLAMS, Cognitive, Language, Developmental Disorders

Cite This Article: Widnyani, I.G.I.A., Windiani, I.G.A.T., Adnyana, I.G.A.N.S., Soetjiningsih. 2020. Gambaran perkembangan kognitif dan bahasa pada anak usia di bawah 3 tahun di Taman Pengasuhan Anak (TPA)/(Daycare) Kota Denpasar, Bali. Intisari Sains Medis 11(1): 216-222. DOl: 10.15562/ism.v11i1.539

Latar Belakang: Gangguan perkembangan bicara dan bahasa dapat memengaruhi berbagai fungsi dalam kesulitan belajar. Hal ini sering terjadi pada anak yang kurang mendapat stimulasi dikarenakan saat ini banyak orang tua bekerja sehingga pengasuhan terhadap anak akan berkurang. Oleh karena itu Taman pengasuhan anak (TPA) dapat menjadi pilihan tempat untuk menitipkan anak sehingga diharapkan mendapatkan stimulasi yang baik sesuai dengan tingkat usia. Penelitian ini bertujuan untuk menilai status perkembangan kognitif dan bahasa pada anak di bawah usia 3 tahun di TPA Kota Denpasar, Bali.

Metode: Penelitian ini menggunakan pendekatan potong lintang terhadap 48 anak yang berada pada 4 TPA di Denpasar pada bulan Februari 2018. Variabel yang dinilai pada penelitian ini meliputi aspek kognitif dan bahasa dimana menggunakan kuisioner cognitif adaptive test (CAT)/clinical linguistic \& auditory milestone scale (CLAMS) yang sahih dan reliabel. Data penelitian yang diperoleh dianalisis menggunakan piranti lunak SPSS versi 19 untuk Windows.

Hasil: Sebagian besar responden berjenis kelamin perempuan $(56,3 \%)$, usia rata-rata $19,5 \pm 10,0$ bulan, dan tingkat pendidikan yang tinggi baik pada ayah $(87,5 \%)$ maupun ibu $(91,7 \%)$. Hasil Caput Scale

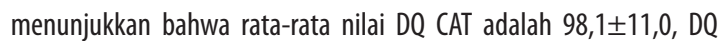

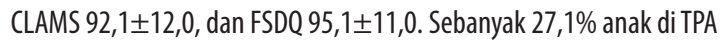
memiliki nilai FSDQ tidak normal. Nilai FSDQ karakteristik responden menunjukkan sebagian besar nilai normal diperoleh pada laki-laki $(76,2 \%)$, Pendidikan tinggi ayah $(78,5 \%)$ dan ibu $(77,2)$, maupun pekerjaan PNS pada ayah $(73,3)$ dan ibu $(78,6)$

Simpulan: Anak yang mengalami gangguan fungsi kognitif dan bahasa di TPA sebanyak 27,1\% melalui pemeriksaan CAT/CLAMS. Berkaitan dengan hal tersebut maka penilaian lebih lanjut dengan desain penelitian yang lebih baik diperlukan untuk mencari hubungan sebab akibat.
Fakultas Kedokteran, Universitas Udayana/RSUP Sanglah, Bali, Indonesia;

dr.agungwidnyani@gmail.com

Diterima: 19-06-2019

Disetujui: 19-03-2020

Diterbitkan: 26-03-2020
Kata kunci: TPA, CAT/CLAMS, Kognitif, Bahasa, Gangguan Perkembangan

Cite Pasal Ini: Widnyani, I.G.I.A., Windiani, I.G.A.T., Adnyana, I.G.A.N.S., Soetjiningsih. 2020. Gambaran perkembangan kognitif dan bahasa pada anak usia di bawah 3 tahun di Taman Pengasuhan Anak (TPA)/(Daycare) Kota Denpasar, Bali. Intisari Sains Medis 11(1): 216-222. DOl: $10.15562 /$ ism.v11i1.539 


\section{PENDAHULUAN}

Tahun pertama kehidupan anak, merupakan pondasi penting terhadap perkembangan bicara anak. Kemampuan bahasa merupakan indikator penting dalam tahap perkembangan anak, karena sensitif terhadap keterlambatan dan kemampuan lain seperti kemampuan kognitif. ${ }^{1}$ Perkembangan kognitif terdiri dari perkembangan bahasa dan visual-motor. Tiga komponen utama dari perkembangan kognitif adalah atensi, pengolahan informasi dan memori. ${ }^{2-4}$ Anak dengan gangguan perkembangan akan mengalami kesulitan dalam mempelajari hal-hal baru, berkomunikasi dengan orang lain (menyampaikan perasaan dan kebutuhannya) dan memiliki teman baru dan berinteraksi dengan orang lain. ${ }^{1}$ Penelitian yang dilakukan oleh Scheffler et al., pada tahun 2008 menyatakan gangguan perkembangan pada anak sebanyak $8 \%$ merupakan gangguan komunikasi dan gangguan kognitif. $^{5}$

Data yang didapat dari RS Dr. Kariadi selama tahun 2007 di Poliklinik Tumbuh Kembang Anak didapatkan 22,9\% dari 436 kunjungan baru datang dengan keluhan terlambat bicara, $13(2,98 \%)$ di antaranya didapatkan gangguan perkembangan bahasa. ${ }^{6}$ Penelitian yang dilakukan oleh Dhamayanti $\mathrm{M}$ et al., menyatakan prevalensi terjadinya gangguan komunikasi dan kognitif adalah sebanyak $8 \% .^{7}$ Sebuah penelitian di tempat penitipan anak menemukan sebesar $14,3 \%$ anak menunjukkan gangguan kognitif dan bahasa. ${ }^{8,9}$ Sebanyak $12-16 \%$ anak-anak di Amerika Serikat diperkirakan mengalami gangguan perkembangan dan perilaku. ${ }^{8}$

Salah satu alat skrining perkembangan kognitif dan bahasa adalah Capute scales. Capute scales merupakan alat skrining yang dapat menilai secara akurat aspek perkembangan utama termasuk komponen bahasa dan visual-motor. ${ }^{6,8}$ Alat skrining ini dikenal cepat dan mudah dalam penggunaannya, sehingga identifikasi dini gangguan perkembangan kognitif dan bahasa dapat segera diketahui sehingga intervensi yang melibatkan banyak pihak dapat segera diberikan. ${ }^{6,8}$

Capute scales terdiri atas 2 jenis pemeriksaan yaitu cognitive adaptive test (CAT) dan clinical linguistic and auditory milestone scale (CLAMS). ${ }^{3,9,10}$ Caput Scales memiliki validitas yang sama dengan gold standard Bayley Scales of Infant Development. ${ }^{7}$ Aplikasi klinis dari pemeriksaan Capute Scales adalah pemeriksaan CLAMS, yang berguna mengukur milestones bahasa reseptif dan ekspresif. Clinical linguistic and auditory milestone scale (CLAMS) mengisi 26 milestone bahasa ekspresif yang meliputi 19 tingkat usia pengujian, yaitu usia 1-12 bulan (interval 1 bulan), usia 14,16,18 bulan (interval 2 bulan), usia 21 dan 24 bulan (interval 3 bulan), usia 30 dan 36 bulan (interval 6 bulan). Evaluasi terhadap milestone bahasa reseptif diperoleh dari kombinasi laporan orangtua dan demonstrasi langsung. ${ }^{7}$

Kemampuan kognitif anak tidak terlepas dari pertumbuhan otak. Pertumbuhan otak tercepat terjadi pada trimester ketiga kehamilan sampai 2 tahun pertama setelah lahir. Pembelahan sel-sel otak yang pesat berupa laju proliferasi neuron, pertumbuhan dan diferensiasi, mielinisasi dan sinaptogenesis terjadi pada fase ini atau 1000 hari pertama kehidupan.,10 Delapan puluh persen perkembangan otak sudah terjadi pada usia 2 tahun, sehingga nutrisi dan stimulasi yang baik pada tahun ini berperan penting terhadap kemampuan kognitif seorang anak. Perkembangan bahasa pada usia bawah lima tahun (balita) akan berkembang sangat aktif dan pesat. Keterlambatan bahasa pada periode ini, akan dapat menimbulkan berbagai masalah dalam proses belajar., ${ }^{1,10}$

Pertumbuhan dan perkembangan seorang anak tidak terlepas dari peran orangtua dan keluarga dalam memberikan pengasuhan dan pendidikan pada anak di rumah. Saat ini masalah perekonomian menyebabkan banyak orangtua untuk bekerja, sehingga waktu yang diberikan kepada anak untuk memberikan kasih sayang, pengasuhan dan pendidikan akan berkurang. ${ }^{11}$ Data terhadap laporan ketenagakerjaan Indonesia tahun 2017 menyebutkan bahwa antara tahun 1996 dan 2016 jumlah tenaga kerja mengalami peningkatan hingga lebih dari 34 juta jiwa. ${ }^{12}$ Rata-rata per tahun penambahan jumlah tenaga kerja sebanyak 1,74 juta. $^{12}$ Jumlah ketenagakerjaan perempuan mengalami peningkatan dalam satu dasawarsa terakhir $(48 \%, 2016)$, sedangkan ketenagakerjaan lelaki sebanyak 62,6\%.12 Dampak saat orangtua bekerja maka anak-anak akan diasuh oleh anggota keluarga lain (kakek, nenek, bibi, paman), pengasuh atau di taman pengasuhan anak (TPA/DAYCARE).

Taman pengasuhan anak (TPA/DAYCARE) merupakan tempat pelayanan pengasuhan dan pengembangan potensi anak usia dini yang bersifat nonformal. TPA ditujukan untuk anak sejak usia 3 bulan sampai 6 tahun. TPA diarahkan untuk pendidikan tumbuh kembang, sehingga tidak bertujuan hanya untuk tempat penitipan saja melainkan dapat memberikan kontribusi positif terhadap perkembangan anak. ${ }^{13}$

Prinsip umum yang diterapkan dalam program TPA/DAYCARE didasarkan pada: berorientasi pada kebutuhan anak yaitu asah, asih dan asuh yang sesuai dengan perkembangan anak. ${ }^{13}$ Kegiatan belajar dilakukan melalui bermain. Anak belajar 
dari yang konkrit ke abstrak. Anak sebagai pembelajar aktif, melalui interaksi sosial, menyediakan lingkungan yang mendukung proses belajar, merangsang munculnya kreatifitas dan inovatif, mengembangkan kecakapan hidup anak, menggunakan berbagai sumber dan media belajar yang ada di lingkungan sekitar. Anak belajar sesuai dengan kondisi sosial budayanya, melibatkan peran serta orangtua, stimulasi pendidikan bersifat menyeluruh yang mencakup semua aspek perkembangan. ${ }^{13}$

Berdasarkan prinsip tersebut maka TPA/ $D A Y C A R E$ selayaknya tidak hanya menjadi tempat penitipan, tetapi taman pengasuhan yang memberikan stimulasi dini yang baik terhadap anak-anak. Skrining dan evaluasi tingkat perkembangan kognitif dan bahasa pada anak di TPA perlu untuk dilakukan. Penelitian ini bertujuan untuk menilai status perkembangan kognitif dan bahasa anak dengan menggunakan penilaian Capute scales pada anak di TPA/DAYCARE. Maanfaat yang diharapkan dari penelitian ini adalah dapat melakukan deteksi dini terhadap fungsi kognitif dan bahasa, sehingga dapat dilakukan intervensi dini terhadap gangguan perkembangan yang terjadi.

\section{METODE}

Penelitian ini merupakan suatu penelitian cross sectional descriptive study melalui wawancara dengan menggunakan kuisioner cognitif adaptive test (CAT)/clinical linguistic \& auditory milestone scale (CLAMS) yang diisi dan diuji oleh dokter. Penelitian ini dilakukan pada anak-anak yang dititipkan di TPA/DAYCARE Denpasar. Penelitian dilakukan dari bulan Februari 2018 sampai jumlah subjek terpenuhi.

Populasi target adalah anak usia $£ 36$ bulan yang dititip di TPA/DAYCARE Denpasar. Populasi terjangkau adalah anak usia $£ 36$ bulan yang terdata di TPA Sayang Ibu, TPA Werdhi Kumara, TPA Pandu, TPA Happy House. Pemilihan keempat TPA berdasarkan purposive sampling. Subjek dipilih secara cluster sampling. Kriteria inklusi adalah semua anak usia $£ 36$ bulan, dan kriteria eksklusi adalah: anak yang memiliki keterbatasan yang berat atau menyeluruh dalam bahasa ekspresi atau fungsi sistem komunikasi apapun, misalnya anak dengan gangguan pendengaran, palatochisis; anak dengan defisit motorik dan kognisi yang berat yang mengakibatkan anak tidak dapat menjalani penilaian perkembangan/kognisi anak, misalnya palsi serebral, hidrosefalus, anak yang mempunyai riwayat infeksi otak, epilepsi, autisme dan keluarga yang menolak berpartisipasi. Besar sampel dihitung dengan menggunakan rumus sampel untuk uji estimasi proporsi pada satu populasi dimana. ${ }^{15}$ Hasil perhitungan sampel menunjukkan sebanyak
48 responden penelitian terlibat dalam penelitian ini.

Data penelitian meliputi: nilai Developmental Quotient (DQ) CAT/CLAMS, dibagi menjadi normal dan tidak normal. Kategorikal normal (1), jika pada kemampuan bahasa dan visual-motor $>85$. Kategori tidak normal (2), jika pada satu atau kedua DQ untuk kemampuan bahasa dan visual-motornya $£ 85{ }^{8,9}$ Full-scale (composite) developmental quotient (FSDQ), dibagi menjadi normal dan tidak normal. Kategori normal (1), jika DQ CAT dan DQ CLAMS $>85$. Kategori tidak normal (2), jika salah satu atau kedua nilai DQ CAT/DQ CLAMS $£ 85$. Usia adalah usia kronologis yaitu usia anak sebenarnya (dalam bulan) saat dilakukan tes. Tingkat pendidikan ayah dan atau ibu (skala kategorikal) adalah dibagi menjadi pendidikan rendah (1), yaitu: tamat SD, tamat SMP/sederajat, tamat SMA sederajat. Kategori pendidikan tinggi (2), yaitu: Diploma dan Sarjana. Pekerjaan ayah dan atau ibu adalah dikelompokkan Pegawai Negeri Sipil (PNS) (1), Bukan PNS (2) seperti karyawan swasta, buruh, petani, ibu rumah tangga. Analisis data menggunakan SPSS versi 19 utuk Windows dan melampirkan data deskriptif dalam bentuk tabel.

\section{HASIL}

Sebanyak 48 subjek dari empat TPA di Denpasar telah dilakukan pemerikasaan cognitif adaptive test (CAT)/clinical linguistic \& auditory milestone scale (CLAMS). Karakteristik subjek penelitian ditampilkan dalam Tabel 1. Berdasarkan karakteristik jenis kelamin, didapatkan bahwa jumlah subjek perempuan $(56,3 \%)$ lebih banyak daripada jenis kelamin lelaki (43,7\%), rerata usia adalah 19,5 $\pm 10,0$ bulan. Tingkat pendidikan orang tua terbanyak adalah pendidikan tinggi pada ayah $(87,5 \%)$ dan ibu (91,7\%). Tingkat pekerjaan orang tua, terbanyak adalah pekerjaan Non-PNS pada ayah $(68,8 \%)$ dan ibu (70,8\%) (Tabel 1).

Pada Tabel 1, persentase anak dengan nilai DQ CAT dan DQ CLAMS tidak normal sebanyak $12,5 \%$ dan $29,2 \%$. Nilai total yang dinyatakan dalam FSDQ menyatakan bahwa persentase terbanyak adalah anak dengan perkembangan kognitif dan bahasa yang normal, yaitu sebanyak $72,9 \%$, sedangkan nilai FSDQ yang menyatakan perkembangan kognitif dan bahasa tidak normal sebanyak 27,1\% (Tabel 1).

Tabel 2 menunjukkan bahwa pada anak dengan nilai FSDQ yang tidak normal, sebagian besar kasus diperoleh pada anak dengan jenis kelamin perempuan $(29,6 \%)$ dibandingkan pada laki-laki $(23,8 \%)$. Tingkat pendidikan ayah $(66,7 \%)$ dan ibu $(75,0 \%)$ dengan pendidikan rendah memiliki persentase 
Tabel 1 Gambaran karakteristik subjek penelitian dan hasil penilaian Caput Scale

\begin{tabular}{|c|c|c|}
\hline Variabel & Jumlah $(\mathbf{N}=48)$ & Rerata \pm SB \\
\hline \multicolumn{3}{|l|}{ Jenis kelamin (n,\%) } \\
\hline Lelaki & $21(43,7)$ & \\
\hline Perempuan & $27(56,3)$ & \\
\hline Usia (bulan) & & $19,5 \pm 10,0$ \\
\hline \multicolumn{3}{|c|}{ Tingkat pendidikan ayah (n,\%) } \\
\hline Pendidikan rendah & $6(12,5)$ & \\
\hline Pendidikan tinggi & $42(87,5)$ & \\
\hline \multicolumn{3}{|c|}{ Tingkat pendidikan ibu (n,\%) } \\
\hline Pendidikan rendah & $4(8,3)$ & \\
\hline Pendidikan tinggi & $44(91,7)$ & \\
\hline \multicolumn{3}{|c|}{ Tingkat pekerjaan ayah (n,\%) } \\
\hline PNS & $15(31,2)$ & \\
\hline Non PNS & $33(68,8)$ & \\
\hline \multicolumn{3}{|c|}{ Tingkat pekerjaan ibu (n,\%) } \\
\hline PNS & $14(29,2)$ & \\
\hline Non PNS & $34(70,8)$ & \\
\hline DQ CAT (skor) & & $98,1 \pm 11,0$ \\
\hline \multicolumn{3}{|l|}{ DQ CAT, n (\%) } \\
\hline Tidak normal & $6(12,5)$ & \\
\hline Normal & $42(87,5)$ & \\
\hline DQ CLAMS (skor) & & $92,1 \pm 12,0$ \\
\hline \multicolumn{3}{|l|}{ DQ CLAMS, n (\%) } \\
\hline Tidak normal & $14(29,2)$ & \\
\hline Normal & $34(70,8)$ & \\
\hline FSDQ (skor) & & $95,1 \pm 11,0$ \\
\hline \multicolumn{3}{|l|}{ FSDQ, n (\%) } \\
\hline Tidak normal & $13(27,1)$ & \\
\hline Normal & $35(72,9)$ & \\
\hline
\end{tabular}

SB: simpang baku; PNS: Pegawai Negeri Sipil; FSDQ: Full-scale (composite) developmental quotient; DQ: Developmental Quotient; CAT: Cognitif Adaptive Test; CLAMS: Clinical Linguistic \& Auditory Milestone Scale

Tabel 2 Distribusi nilai FSDQ terhadap karakteristik responden penelitian

\begin{tabular}{lcc}
\hline & \multicolumn{2}{c}{ FSDQ (N=48) } \\
\cline { 2 - 3 } Variabel & Tidak normal $\mathbf{( N = 1 3 )}$ & Normal (N=35) \\
\hline Jenis kelamin (n,\%) & $5(23,8)$ & $16(76,2)$ \\
$\quad$ Lelaki & $8(29,6)$ & $19(70,4)$ \\
$\quad$ Perempuan & & \\
Tingkat pendidikan ayah (n,\%) & $4(66,7)$ & $2(33,3)$ \\
$\quad$ Pendidikan rendah & $9(21,5)$ & $33(78,5)$ \\
$\quad$ Pendidikan tinggi & & $1(25,0)$ \\
Tingkat pendidikan ibu (n,\%) & $3(75,0)$ & $34(77,2)$ \\
$\quad$ Pendidikan rendah & $10(22,8)$ & \\
$\quad$ Pendidikan tinggi &
\end{tabular}


Tabel 2 Continue

\begin{tabular}{lcc}
\hline & \multicolumn{2}{c}{ FSDQ (N=48) } \\
\cline { 2 - 3 } Variabel & Tidak normal (N=13) & Normal (N=35) \\
\hline Tingkat pekerjaan ayah (n,\%) & $4(26,7)$ & $11(73,3)$ \\
$\quad$ PNS & $9(27,3)$ & $24(72,7)$ \\
$\quad$ Non-PNS & & \\
Tingkat pekerjaan ibu (n,\%) & $3(21,4)$ & $11(78,6)$ \\
$\quad$ PNS & $10(29,4)$ & $24(70,6)$ \\
Non-PNS & & \\
\hline
\end{tabular}

PNS: pegawai negeri sipil; FSDQ: Full-scale (composite) developmental quotient

terbanyak anak dengan nilai FSDQ tidak normal. Nilai FSDQ tidak normal terbanyak terjadi pada anak dengan tingkat pekerjaan baik ayah (27,3\%) dan ibu $(29,4 \%)$ adalah bekerja sebagai non-PNS (Tabel 2).

\section{PEMBAHASAN}

Skrining rutin perkembangan pada setiap anak sehat atau pada anak yang dicurigai mengalami keterlambatan merupakan rekomendasi yang dikeluarkan oleh American Academy of Pediatrics (AAP). Perkembangan merupakan perubahan yang bersifat progresif, terarah dan terpadu. Perkembangan kognitif, fisik dan psikososial masing-masing tidak bisa digambarkan secara terpisah, karena ketiganya berpengaruh satu sama lain. Masa kritis perkembangan anak perlu mendapat perhatian. ${ }^{15}$ Perkembangan yang optimal terjadi apabila maturitas sistem susunan saraf dengan fungsi yang baik, lingkungan yang kondusif untuk setiap tahap tumbuh kembang anak. Anak merupakan dambaan setiap keluarga, serta sebagai aset suatu bangsa, sehingga stimulasi dan evaluasi terhadap tumbuh dan kembang anak pada masa kritis perkembangan anak perlu rutin dilakukan. ${ }^{15,16}$

Berdasarkan penelitian ini status perkembangan normal $72,9 \%$ yang didapatkan sedikit berbeda dari penelitian yang dilakukan sebelumnya. Hasil dari penelitian sebelumnya oleh Hartanto F et al., $84 \%$ subjek memiliki perkembangan normal berdasarkan skrining CAT/CLAMS. ${ }^{6}$ Hasil yang sama juga terjadi pada penelitian yang dilakukan oleh Windiani IGAT dan Soetjiningsih di TPA Werdhi Kumara 1 Denpasar, dengan persentase perkembangan normal sebesar $83,7 \% .^{9}$ Perbedaan hasil ini dapat disebabkan oleh karena tempat penelitian yang dilakukan adalah berbeda yaitu di RS Dr. Kariadi Semarang dan pada satu TPA/ DAYCARE saja, sedangkan pada penelitian ini dilakukan pada empat TPA/DAYCARE sehingga jumlah persentase ini merupakan penjumlahan dari keempat TPA. Anak dengan jenis kelamin perempuan lebih banyak mengalami perkembangan tidak normal dibandingkan lelaki, yaitu sebanyak 29\%. Hasil tersebut sama dengan penelitian yang dilakukan Felfe $\mathrm{C}$ dan Lalive $\mathrm{R}$ dimana anak lelaki lebih baik dalam peningkatan perkembangan daripada perempuan. ${ }^{11}$ Berbeda dari penelitian yang dilakukan oleh Hartanto $\mathrm{F}$ et al., dimana perkembangan tidak normal lebih banyak terjadi pada anak lelaki. ${ }^{6}$ Perbedaan hasil ini bisa disebabkan jumlah subjek pada penelitian ini persentase lebih banyak adalah perempuan.

Anak dengan perkembangan tidak normal pada penelitian ini terjadi lebih banyak pada orangtua dengan pendidikan rendah, hal ini sesuai dengan penelitian yang menyebutkan bahwa tingkat pendidikan rendah pada orangtua berhubungan dengan risiko anak mengalami gangguan perkembangan. ${ }^{11}$ Semakin tinggi pendidikan orangtua maka kemampuan orangtua untuk dapat mendidik, mengasuh, mengetahui cara dan mengakses informasi yang berguna untuk perkembangan anak samakin baik. Salah satu informasi yang bisa didapatkan dalam hal cara mengasuh yang baik untuk perkembangan anak adalah bermain dengan alat-alat permainan edukatif (APE), tidak dianjurkan menonton televisi (TV) pada anak di bawah usia 2 tahun, dapat menonton 1-2 jam pada anak anak usia di atas 2 tahun dengan pendampingan dan tidak dianjurkan memberikan permainan menggunakan handphone (HP). Tingkat pendidikan orangtua yang tinggi diasumsikan dapat menerima dan menerapkan informasi-informasi yang berguna untuk perkembangan buah hatinya.

Tingkat pekerjaan orangtua sebagai non PNS terbanyak mengalami anak dengan perkembangan tidak normal. Keadaan ini dapat disebabkan oleh waktu jam kerja dari orangtua yang tidak tetap, jika dibandingkan dengan orangtua yang bekerja sebagai PNS. Sedikitnya waktu yang dimiliki oleh orangtua untuk bersama anak, maka kuantitas dan kualitas waktu untuk mengasuh, bermain, memberikan kasih sayang dan mendidik juga diasumsikan berkurang. 
Jumlah persentase total anak dengan perkembangan tidak normal pada penelitian ini adalah sebanyak 27\%, jumlah ini lebih tinggi bila dibandingkan dengan penelitian oleh Windiani IGAT dan Soetjiningsih yang dilakukan di TPA Werdhi Kumara Denpasar yaitu sebanyak 14,3\%. ${ }^{9}$ Peningkatan persentase tersebut dapat disebabkan penelitian ini dilakukan pada empat TPA yang berbeda dari penelitian sebelumnya. Berbeda dengan penelitian yang dilakukan oleh Felfe $\mathrm{C}$ dan Lalive $\mathrm{R}$ mengenai perkembangan anak yang dititip di TPA/DAYCARE, menyatakan bahwa semakin dini seorang anak mendapatkan pengasuhan di TPA/DAYCARE, perkembangan bahasa, motorik dan sosial semakin baik. ${ }^{11}$ Akan tetapi, perbedaan jumlah anak dengan perkembangan tidak normal pada penelitian ini, dapat disebabkan syarat dari TPA/DAYCARE yang baik belum terpenuhi, salah satunya adalah; (1) keempat TPA/DAYCARE, rasio dari pengasuh dan anak yang di TPA/ DAYCARE, tidak memenuhi syarat sesuai peraturan Kementerian Pendidikan dan Kebudayaan 2013, yaitu rasio pengasuh/pendidik lebih sedikit dibandingkan dengan jumlah anak didik. Metode pembelajaran di TPA/DAYCARE berdasarkan peraturan Kementerian Pendidikan dan Kebudayaan 2013, meliputi metode bercerita, demonstrasi, bercakap-cakap, pemberian tugas, sosio-drama, karyawisata, proyek, eksperimen. ${ }^{13}$ Salah satu syarat dari komponen penyelenggaraan TPA/DAYCARE adalah dari tenaga pendidik adalah berpendidikan minimal Diploma atau Sarjana dengan rasio guru dengan anak pada kelompok usia $0-<2$ tahun adalah 1:4, usia 2-4 tahun adalah 1:8, usia 4-6 tahun adalah 1:15. ${ }^{13}$ Dampak yang bisa diakibatkan adalah perhatian dalam pengasuhan maupun pembelajaran tidak akan optimal. (2) metode pembelajaran yang dilakukan pada TPA/DAYCARE masih kurang, dimana masing-masing TPA/DAYCARE memiliki TV sehingga anak lebih banyak menonton, tidak ada metode pembelajaran karyawisata keluar lingkungan maupun ekperimen. Taman pengasuhan anak yang baik, seharusnya mempunyai langkah-langkah kegiatan dalam pembelajaran yang disesuaikan berdasarkan kelompok usia. Kegiatan dapat diatur sebagai berikut; kegiatan penyambutan peserta didik, kegiatan bermain bebas, kegiatan latihan buang air besar, buang air kecil, membersihkan diri dan minum, kegiatan persiapan makan siang, mendengarkan cerita untuk tidur siang, kegiatan tidur siang, kegiatan bermain dan makan kudapan sore, kegiatan mandi sore dan beribadah, kegiatan menunggu jemputan dengan membaca buku, bermain mainan edukatif, merapikan mainan, serta persiapan untuk pulang. ${ }^{13}$ Layanan yang diberikan di TPA/DAYCARE seharusnya bersifat holistik dan integratif. ${ }^{15,16}$ Kemudian yang ke (3) penelitian ini tidak melakukan analisis terhadap recall asupan nutrisi sebelum usia 2 tahun serta status gizi. Asupan nutrisi yang baik pada masa pertumbuhan dan perkembangan otak penting untuk berkembangnya otak secara optimal. Pertumbuhan otak tercepat terjadi pada trimester ketiga kehamilan sampai 2 tahun pertama kehidupan, pada masa ini terjadi pembelahan sel-sel otak terjadi sangat cepat setelah itu pembelahan akan melambat. Delapan puluh persen perkembangan otak sudah terjadi pada usia 2 tahun, sehingga pada masa ini adalah masa yang rawan untuk pertumbuhan jaringan otak. Adanya gangguan atau nutrisi yang tidak baik, dapat mengakibatkan gangguan jumlah sel otak dan mielinisasi yang tidak bisa dikejar lagi pada masa pertumbuhan berikutnya. ${ }^{1}$ (4) orang yang mengasuh anak saat di rumah, cara pengasuhan yang dilakukan serta pola asuh yang diterapkan terhadap anak (pola asuh otoriter, permisif atau demokratis) belum dilakukan analisis lebih lanjut pada penelitian ini. Kondisi ini dapat memengaruhi hasil dari penelitian ini.

Untuk dapat memberikan kontribusi positif terhadap perkembangan pada anak di suatu TPA/ DAYCARE, faktor yang berpengaruh adalah kualitas dari pengasuhan yang diberikan. TPA yang memiliki kualitas yang tinggi, tidak hanya menjadi tempat yang aman tetapi dapat memberikan hubungan terhadap pengasuh dan lingkungan yang baik untuk merangsang proses pembelajaran dalam perkembangan anak. ${ }^{17}$

Kelemahan dari penelitian ini yaitu desain deskriptif tidak dapat menganalisa variabel-variabel tersebut diatas terhadap perkembangan anak, pemeriksaan skrining CAT/CLAMS dilakukan oleh 4 dokter, sehingga risiko terjadinya bias dalam pemeriksaan. Belum dilakukan evaluasi terhadap bagaimana cara memberikan stimulasi, lama, dan siapa yang sering memberikan stimulasi kepada anak baik di TPA maupun saat dirumah. Belum dilakukan analisis terhadap lama anak dititip di TPA, serta jumlah subjek penelitian yang lebih banyak lagi.

\section{SIMPULAN}

Pada penelitian ini gangguan fungsi kognitif dan bahasa pada anak yang dititip di TPA/ DAYCARE sebesar 27\%. Perlu dilakukan penelitian lebih lanjut dengan desain penelitian yang lebih sesuai untuk mendapatkan hubungan variabel-variabel yang berpengaruh terhadap perkembangan anak.

\section{KONFLIK KEPENTINGAN}

Tidak terdapat konflik kepentingan dalam pengerjaan penelitian ini. 


\section{ETIKA PENELITIAN}

Persetujuan etik telah diperoleh oleh Komisi Etik, Fakultas Kedokteran, Universitas Udayana, Bali, Indonesia sebelum penelitian berjalan.

\section{PENDANAAN}

Penulis bertanggung jawab terhadap pendanaan penelitian tanpa melibatkan pihak sponsor manapun.

\section{KONTRIBUSI PENULIS}

Seluruh penulis berkontribusi dalam penelitian ini baik dari tahap pembuatan kerangka konsep, pengumpulan data, analisis data, hingga interpretasi hasil penelitian dalam bentuk publikasi penelitian.

\section{DAFTAR PUSTAKA}

1. Fink G, Rockers PC. Childhood growth, schooling, and cognitive development: further evidence from the Young Lives study. Am J Clin Nutr. 2014;100(1):182-188.

2. Valla L, Wentzel-Larsen T, Hofoss D, Slinning K. Prevalence of suspected developmental delays in early infancy: results from a regional population-based longitudinal study. BMC Pediatr. 2015;15:215.

3. Committee on Children With Disabilities. Role of the pediatrician in family-centered early intervention services. Pediatrics. 2001;107(5):1155-1157.

4. Thapar A, Cooper M, Rutter M. Neurodevelopmental disorders. Lancet Psychiatry. 2017;4(4):339-346.

5. Scheffler F, Vogel D, Astern R, Burgess J, Conneally T, Salerno K. Screening for communication and cognitive disorders in infants and toddlers. Pediatr Nurs. 2007;33(6):473-480
6. Hartanto F, Selina H, Zuhriah H, Fitra S. Pengaruh Perkembangan Bahasa Terhadap Perkembangan Kognitif Anak Usia 1-3 Tahun. Sari Pediatri. 2011;12(6): 386-90.

7. Dhamayanti M, Herlina M. Skrining Gangguan Kognitif dan Bahasa dengan Menggunakan Capute Scales (Cognitive Adaptive Test/Clinical Linguistic \& Auditory Milestone Scale-Cat/Clams). Sari pediatri. 2009;11(3):189-98.

8. Nelson HD, Nygren P, Walker M, Panoscha R. Screening for speech and language delay in preschool children: systematic evidence review for the US Preventive Services Task Force. Pediatrics. 2006;117(2):e298-e319.

9. Windiani IGAT, Soetjiningsih. Penilaian CAT (cognitive adaptive test)/CLAMS (clinical linguistic \& auditory milestone scale) pada Anak di Tempat Penitipan Anak Werdhi Kumara I Denpasar. Sari Pediatri. 2010;12(4):228-32.

10. Grantham-McGregor S, Cheung YB, Cueto S, et al. Developmental potential in the first 5 years for children in developing countries. Lancet. 2007;369(9555):60-70.

11. Felfe C, Lalive R. Does early child care affect children's development?. Journal of Public Economics. 2018;159:33-53

12. Kementerian Ketenagakerjaan Republik Indonesia. Laporan Ketenagakerjaan Indonesia 2017: Memanfaatkan Teknologi untuk Pertumbuhan dan Penciptaan Lapangan Kerja. Organisasi Perburuhan Internasional. 2017

13. Kementerian Pendidikan Nasional. Petunjuk Teknis Penyelenggaraan Taman Penitipan Anak. Jakarta.2015

14. Dahlan SM. Besar Sampel dan Cara Pengambilan Sampel dalam Penelitian Kedokteran dan Kesehatan. Edisi ke-3. Jakarta: Salemba Medika. 2013.

15. Lake A, Chan M. Putting science into practice for early child development. Lancet. 2015;385(9980):1816-1817.

16. Vaivre-Douret L. Developmental and cognitive characteristics of "high-level potentialities" (highly gifted) children. Int J Pediatr. 2011;2011:420297.

17. Blau DM. The effect of child care characteristics on child development. The Journal of Human Resources. 2014;34(4):786-822.

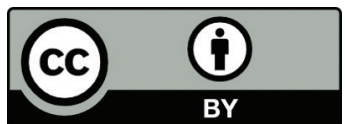

This work is licensed under a Creative Commons Attribution 